Proceeding Paper

\title{
Advances in Visual Immunoassays for Sensitive Detection of Mycotoxins in Food-A Review ${ }^{\dagger}$
}

\author{
Meijuan Liang ${ }^{1,2,3,4,5}$ (D) Qi Zhang ${ }^{1,2,3,4,5, *}$ and Peiwu Li 1,2,3,4,5,*
}

check for updates

Citation: Liang, M.; Zhang, Q.; Li, P. Advances in Visual Immunoassays for Sensitive Detection of Mycotoxins in Food-A Review. Chem. Proc. 2021, 5, 25. https://doi.org/10.3390/ CSAC2021-10443

Academic Editor: Huangxian Ju

Published: 30 June 2021

Publisher's Note: MDPI stays neutral with regard to jurisdictional claims in published maps and institutional affiliations.

Copyright: (c) 2021 by the authors. Licensee MDPI, Basel, Switzerland. This article is an open access article distributed under the terms and conditions of the Creative Commons Attribution (CC BY) license (https:/ / creativecommons.org/licenses/by/ $4.0 /)$.
1 Oil Crops Research Institute, Chinese Academy of Agricultural Sciences, Wuhan 430062, China; liangmj@whu.edu.cn

2 Key Laboratory of Biology and Genetic Improvement of Oil Crops, Ministry of Agriculture, Wuhan 430062, China

3 Laboratory of Quality \& Safety Risk Assessment for Oilseed Products (Wuhan), Ministry of Agriculture, Wuhan 430062, China

4 Key Laboratory of Detection for Mycotoxins, Ministry of Agriculture, Wuhan 430062, China

5 Quality Inspection \& Test Center for Oilseed Products, Ministry of Agriculture, Wuhan 430062, China

* Correspondence: zhangqi01@caas.cn (Q.Z.); peiwuli@oilcrops.cn (P.L.)

+ Presented at the 1st International Electronic Conference on Chemical Sensors and Analytical Chemistry (CSAC2021), 1-15 July 2021; Available online: https: / / sciforum.net/conference/CSAC2021.

\begin{abstract}
Mycotoxins are the toxic secondary metabolites naturally produced by fungi; their contamination in agricultural products and food severely threatens food safety and public health worldwide. The reliable, efficient, and sensitive quantification of mycotoxins in food has become increasingly challenging to tackle due to the complexity of food matrices and their low level. Visual detection has emerged as a popular trend toward miniaturization and simplification of mycotoxins assays yet is constrained with their limited sensitivity. This review mainly focuses on the various sensitive visual immunoassays for signal amplified detection of mycotoxins. These signal amplified immunoassays for the improved sensitivity of mycotoxins detection in food through nanomaterials for encapsulation enzyme, enzyme-mediated nanomaterials as the amplified signal readout, and nanozyme. Furthermore, the underlying principle and the advantages of visual immunoassays for mycotoxins have been proposed. And the challenges and perspectives have been proposed to develop improved efficient visual immunoassays for mycotoxins in food.
\end{abstract}

Keywords: mycotoxins; nanomaterials; catalysis; immunoassay; visualization

\section{Introduction}

Mycotoxins are toxic secondary metabolites secreted by fungi under suitable temperature and humidity pre- and/or post-harvest [1-3]. Mycotoxins can affect the quality and safety of agriculture products, the associated processed foodstuffs, feedstuff, and animals. Over 400 mycotoxins have recently been identified, the worldwide occurrence of mycotoxins involving aflatoxin (AF), ochratoxin (OT), zearalenone (ZEN), deoxynivalenol (DON), fumonisin (FB), and T-2 toxin [4,5]. It is well known that aflatoxin is the representative mycotoxins, including $\mathrm{AFB}_{1}, \mathrm{AFB}_{2}, \mathrm{AFG}_{1}$, and $\mathrm{AFG}_{2}$, which has been confirmed to be immunosuppressive, teratogenic, and mutagenic [6,7]. Meanwhile, $\mathrm{AFB}_{1}$ could be metabolized into the toxic hydroxyl metabolite of $\mathrm{AFM}_{1}$, which is widespread presence of milk and dairy products.

Additionally, ZEN with a strong estrogenic effect and OTA with neurotoxicity and hepatotoxicity could adversely affect animals and humans. To protect humans from exposure mycotoxins, strict standards of limiting mycotoxin levels in food and the associated products have been regulated in many countries worldwide [8]. The monitoring of mycotoxins has been recognized as a significant way to safeguard food safety. However, mycotoxins detection in food matrices is challenging due to their low levels and complex food matrices. 
Accordingly, it is highly desirable to conduct the effective, reliable and sensitive analytical strategy for screening mycotoxins in food matrices.

Nowadays, many efforts have been made to detect mycotoxins in food, involving instrumental analysis [9-13] and immunoassays [14-16]. The instrumental analysis requires expensive, sophisticated instruments, a time-consuming sample preparation process, and well-trained staff, which is not suitable for rapid screening numerous samples, and precludes their wide application in resource-constrained regions [17]. Immunoassays have been extensively identified as promising specific recognition for quantifying mycotoxins thanks to their sensitivity, on-site, as well as high-throughput screening capability. The specific recognition interaction between antibody and antigen has generally favored highly selective and reliable monitoring of mycotoxins. Various signal transduction techniques have currently been utilized to conduct mycotoxins immunoassays, such as fluorescence [18-20], electrochemistry [21-24], chemiluminescence [25], and colorimetry [26-28]. Attractively, visual detection, a popular trend toward miniaturization and simplification analysis, is capable of directly observing the results by the naked eye without other sophisticated instruments [29-31].

Currently, various immunoassays involving enzyme-linked immunosorbent assay (ELISA) [32,33], lateral flow immunoassay (LFI) [34-37] have been demonstrated as an excellent platform for discrimination of mycotoxins. Among them, ELISA and LFI served as the representative visual immunoassay, have attracted continuous interest due to their advantages of simple, and on-sites for rapid screening mycotoxins. Yet, the sensitivity of these conventional visual detection methods require improvement to monitor trace amounts of mycotoxins in complex food matrices. Thus, numerous studies have currently been devoted to the construction of the visualized immunoassays for enhancing the sensitivity of mycotoxins detection via signal amplification.

Recently, the robust enzyme catalytic amplification has been confirmed to enhance the sensitivity of immunoassays. Particularly, elaborate enzymatic strategies for improving the limited enzyme amount and the catalytic activity have been engineered as efficient and sensitive immunoassays for high-performance sensing targeted analytes. The emerging nanomaterials with unique optical, electrical, magnetic, and catalytic properties provide new opportunities for improving enzymatic immunoassays [38-42]. More evidence has revealed that the integration of novel nanomaterials promoted sensitivity improvements on mycotoxins detection [43-45]. For instance, Au nanoparticles (AuNPs) functionalized with antibodies, effectively discriminating the immune complex and enzyme to catalytic reaction substrate, significantly elevated their analytical performance [46-48]. Accordingly, the combination of nanomaterials and enzymatic immunoassays provides a potent signal amplified platform for highly sensitive and specific rapidly screening of mycotoxins. Herein, we summarize the improvements on visual immunoassays of mycotoxins by integrating nanomaterials and enzymatic signal amplification. The improvements in sensitivity of mycotoxin in food were emphasized with the assistance of nanomaterials for encapsulation enzyme, enzyme-mediated nanomaterials as the amplified signal readout, and nanomaterials for enzyme-mimics. Challenges and outlook of mycotoxin detection have been proposed to develop improved and efficient visual immunoassays in food.

\section{The Signal Amplified Strategies}

Natural enzymes, as potent biocatalysts have been widely used in countless laboratories, medical and food safety fields thanks to their high catalytic activities, substrate specificity, good biocompatibility, and wide range of biocatalysis [49,50]. ELISA is a classical enzyme-based visual immunoassay, which mainly includes the sorbent substrate, immunorecognition and enzyme labels. The antigen or antibody serves as sorbent substrate to immobilize onto the supporting material, enzyme-labeled molecule then immobilized to sorbent [51]. The sensing principle of ELISA mainly relies on the specific immune reaction between antibodies and antigens. Generally, after precoating the antibody or antigen on the sorbent substrate through physical absorption, the antigen or antibody were captured 
via specific immuno-recognition, and further immobilized on the substrate. The enzymelabeled antibody would bind to the antigens to form a bioconjugation. Significantly, the enzyme catalyzes the colorless chromogenic substrate to generate colorimetric output, and the resultant colorimetric signal is recorded by UV-vis spectrophotometer or microplate reader to quantify the analyte concentration $[52,53]$. The sensitivity of ELISA could be effectively enhanced by improving the absorbent substrate, the recognition element, enzyme label, or chromogenic reagent. Among them, natural enzymes represent robust signal amplification, which has been extensively utilized to develop the highly sensitive immunoassays for trace level mycotoxins because of the catalytically amplified signal.

The peroxidase activity of horseradish peroxidase (HRP) has been used in the traditional ELISA, where HRP served as signal amplification for catalysis $\mathrm{H}_{2} \mathrm{O}_{2}$ into hydroxyl radical $(\bullet \mathrm{OH})$ that can react with the colorless chromogenic substrate $3,3^{\prime}, 5,5^{\prime}-$ tetramethylbenzidine (TMB), 2,2'-azino-bis-(3-ethylbenzthiazoline-6-sulfonic acid) (ABTS) or o-phenylenediamine (OPD) into blue $\mathrm{TMB}_{\mathrm{ox}}$, green $\mathrm{ABTS}^{+} \bullet$, or yellow $\mathrm{OPD}_{\mathrm{ox}}$ under acidic condition. The colorimetric signal intensity is associated with the anchored HRPlabeled antigen or antibody for catalysis chromogenic substrates [54]. Accordingly, the analytes can be quantified through a direct method or an enzyme-labeled secondary antibody. In the previous studies, HRP-labeled antibodies were the most commonly used in the traditional ELISA to realize the various mycotoxin detection in foods [55-59]. The aforementioned ELISA adopted enzyme-labeled secondary antibodies through chemical conjugation to generate a signal. Yet, the chemical conjugation of the enzyme might result in the loss of enzyme activity, low stability for reagents labeling, and decreased sensitivity and specificity of the ELISA [60]. More evidence was revealed that the fusion protein had been recognized as an immunological agent for mycotoxins detection since its good antigen binding and enzyme activity. A nanobody-alkaline phosphatase (ALP) fusion protein has been revealed to improve the sensitivity for $\mathrm{FB}_{1}$ and OTA detection in argo-products [61-63].

Note that the enzyme-labeled antigen or antibody revealed the limited enzyme molecules. For instance, HRP-labeled conjugate always presented the limited HRP molecules with approximately 2-3 HRP per antibody [64], which remarkably weakened the enzymatic signal amplification and the sensitivity of immunoassays. Besides the limited enzyme molecules, the low economy of the conjugated enzyme might lead to an increase the production cost of the immunoassays $[65,66]$. Meanwhile, enzyme-label is susceptible to decreasing or even losing catalytic activity upon practical detection [67]. Thus, the efficient strategies of augmenting enzyme amounts contribute to amplifying the sensitivity of visual immunoassay. Various enzymatic signal amplification immunoassays using nanomaterials as a robust scaffold for enzyme immobilization, enzyme-mediated nanomaterials for amplified signal readout, and nanozyme as an alternative for natural enzyme have recently been used to improve the enzyme loading and catalytic activity.

\subsection{Immobilized Natural Enzymes on Nanomaterials for Amplification}

Increasing the enzyme amounts in the final antigen-antibody-enzyme complex facilitates the catalysis of the substrate and signal amplification in a single recognition reaction (Figure 1A). Attractively, nanomaterials can execute as excellent carriers for loading and immobilizing enzymes by virtue of their large surface area-to-volume ratio, high loading capacity, facile fabrication, ease of functionalization, and high chemical stability. The multienzymes and antibodies immobilized on the surface of a single nanomaterial to effectively amplify the detectable signal, and thus enhance the sensitivity [68]. The emerging nanomaterials of metal/metal oxides nanoparticles, silica nanoparticles [69], carbon nanomaterials, and metal-organic frameworks have been demonstrated as excellent carriers for immobilizing natural enzymes for sensitive analysis. For instance, Zhu et al. utilized botryoid-shaped $\mathrm{Au} / \mathrm{Ag}$ nanoparticles (BSNPs) loading HRP-IgG to construct indirect competitive ELISA for amplified ochratoxin A (OTA) detection in four wheat samples. After precoating the OTA-OVA antigen, the analyte of OTA was introduced as a competing component, followed by the addition of an anti-OTA antibody. Thus HRP-IgG-BSNPs complex was used 
as the enzyme-labeled secondary antibody for catalysis colorless TMB into blue oxidized TMB with the assistance of $\mathrm{H}_{2} \mathrm{O}_{2}$. And the colorimetric intensity was recorded by a microplate reader to examine the OTA level. The high loading amount of HRP-IgG onto the BSNPs contributed to improved sensitivity of OTA with the $\mathrm{IC}_{50}$ of $0.05 \mathrm{ng} / \mathrm{mL}$, which revealed a 30-fold improvement compared to the conventional ELISA [70].

A
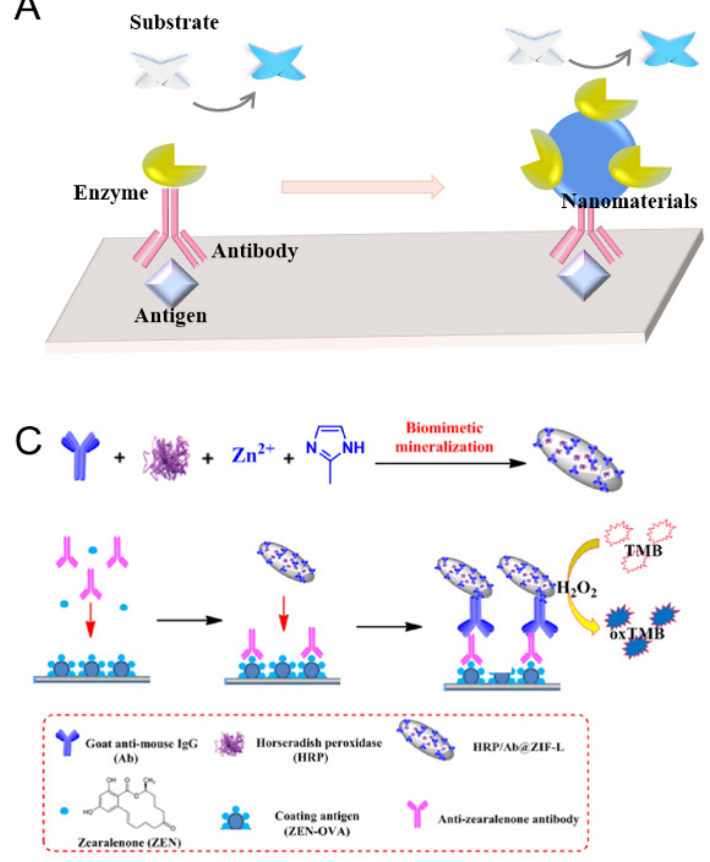

B

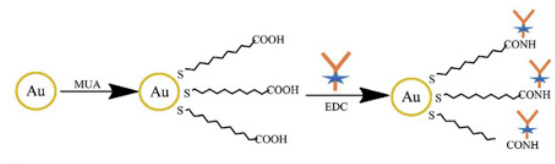

Traditional IC-ELISA

MUA-AuNPs Enhanced IC-ELISA

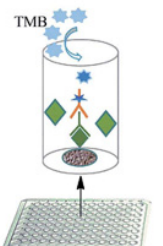

TMB

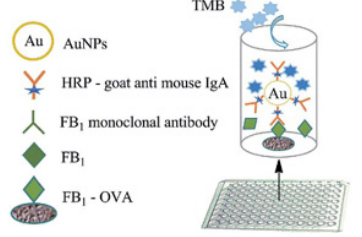

$\mathrm{D}$

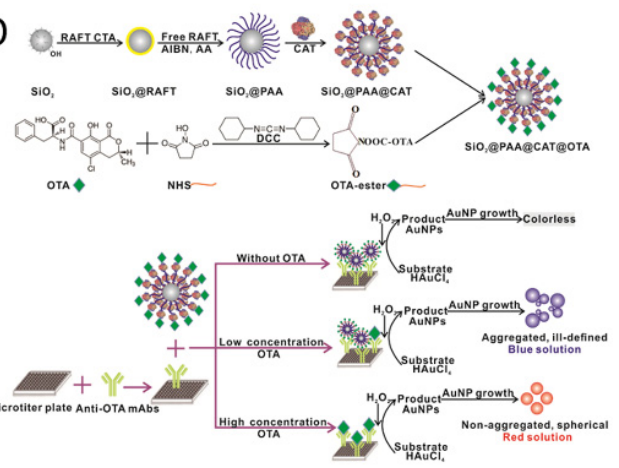

Figure 1. (A) The improved immunoassays using nanomaterials for immobilization natural enzymes. (B) AuNPs-HRP-goat anti-mouse IgA enhanced ELISA for $\mathrm{FB}_{1}$. Reprinted from ref. [71]. Copyright 2018 Royal Society of Chemistry. (C) Zeolitic imidazolate framework-encapsulated HRP-based ELISA for ZEN. Reprinted from ref. [72]. Copyright 2021 Elsevier. (D) $\mathrm{SiO}_{2} \mathrm{NPs}_{\text {carrying poly }}$ (acrylic acid)@CAT-based ELISA for OTA. Reprinted from ref. [73]. Copyright 2016 American Chemical Society.

Similarly, Li et al. [71] developed an indirect competitive ELISA for the total $\mathrm{FB}_{1}, \mathrm{FB}_{2}$, and $\mathrm{FB}_{3}$ detection in maize samples based on AuNPs immobilized HRP-goat anti-mouse IgA. The enhanced sensitivity was approximately ten times compared to the conventional ELISA (Figure 1B). Liu et al. [72] developed metal-organic frameworks (MOFs)-loaded HRP and goat anti-mouse IgG for ZEN detection in argo-products. The LOD of this immunoassay achieved $0.5 \mathrm{ng} / \mathrm{L}$ for ZEN detection, which showed an approximately 126 -fold enhancement relative to conventional HRP-based immunoassay (Figure 1C). Besides single nanomaterials, polymer-coated nanomaterials as enzyme containers have demonstrated to be the amplified strategies of conventional nanomaterials for further elevating the enzyme loading capacity of nanomaterials. Xiong's group presented that $\mathrm{SiO}_{2} \mathrm{NPs}$ carrying poly (acrylic acid) (PAA) brushes as a "CAT container" were used to amplify the sensitivity of OTA in various argo-products [73]. In this case, the $\mathrm{SiO}_{2} @ P A A @ C A T$ could generate a signal amplification for plasmonic ELISA by using catalase (CAT)-catalyzed the changed plasmonic signal readout of AuNPs. The LOD by naked eye and microplate reader was $10^{-18}$ and $5 \times 10^{-20} \mathrm{~g} / \mathrm{mL}$, which was seven and eight orders of magnitude lower than that of CAT-based ELISA $\left(10^{-11} \mathrm{~g} / \mathrm{mL}\right.$ by the naked eye) and HRP-based conventional ELISA $\left(10^{-11} \mathrm{~g} / \mathrm{mL}\right.$ by the microplate reader) (Figure 1D). 


\subsection{Natural Enzyme-Mediated Nanomaterials for Amplified Signal Readout}

In addition to the typical chromogenic substrate, natural enzyme-catalyzed products enable to regulate the color change of nanomaterials, especially for plasmonic property of AuNPs, achieving the visual detection of mycotoxins (Figure 2A). For instance, Xiong's group [74] developed a direct competitive ELISA through CAT-mediated AuNPs aggregation using $\mathrm{HRP}+\mathrm{H}_{2} \mathrm{O}_{2}+$ tyramine system. In this case, phenol polymerization of tyramine by $\bullet \mathrm{OH}$ from HRP-catalyzed $\mathrm{H}_{2} \mathrm{O}_{2}$ triggered AuNPs aggregation. The competitive antigen of OTA-labeled CAT was employed to catalyze $\mathrm{H}_{2} \mathrm{O}_{2}$ into $\mathrm{H}_{2} \mathrm{O}$ and $\mathrm{O}_{2}$. AuNPs presented monodisperse (red) without OTA, while the AuNPs aggregation (blue) was observed with OTA, and the extinction spectra of AuNPs were used as the signal recorder. The combined advantages of ultrahigh CAT catalytic activity and color change of AuNPs contributed to sensitively detecting OTA in corn samples. The $\mathrm{IC}_{50}$ and $\mathrm{LOD}\left(\mathrm{IC}_{10}\right)$ of OTA were 84.75 and $17.8 \mathrm{pg} / \mathrm{mL}$, which revealed a 2.9- and 2.7-fold enhancement compared with the conventional ELISA (Figure 2B).

Meanwhile, this group also utilized the glucose oxidase $\left(\mathrm{GO}_{\mathrm{x}}\right)$-catalyzed glucose into $\mathrm{H}_{2} \mathrm{O}_{2}$, which reduces $\mathrm{Au}^{3+}$ into $\mathrm{Au}^{0}$ on the surface of $\mathrm{Au}$ seeds with an obvious color change for a direct competitive ELISA for $\mathrm{FB}_{1}$ detection in maize samples. The $\mathrm{IC}_{50}$ was $1.86 \mathrm{ng} / \mathrm{mL}$, approximately 13-fold lower than that of HRP-based conventional ELISA [75]. Apart from AuNPs, enzyme-assisted etching of Au nanorods (NRs) triggered visual detection of mycotoxins. HRP-assisted AuNRs-etching direct competitive ELISA was developed to sensitively detect $\mathrm{AFB}_{1}$ in corn samples. The competitive antigen of $\mathrm{AFB}_{1}$-labeled $\mathrm{GO}_{x}$ could catalyze glucose molecules into $\mathrm{H}_{2} \mathrm{O}_{2}$, and HRP simultaneously catalyze $\mathrm{H}_{2} \mathrm{O}_{2}$ to form $\bullet \mathrm{OH}$. The rod-like morphology AuNRs was chemically etched to spherical morphology by $\bullet \mathrm{OH}$, leading to visual signal output. The etching process of AuNRs efficiently occurred without $\mathrm{AFB}_{1}$, yet the blocking of AuNRs etching was clearly presented in the presence of $\mathrm{AFB}_{1}$. The decreased optical density and the apparent color change from bluish-green to red were collected by a microplate reader or the naked eye for qualitative $\mathrm{AFB}_{1}$ detection. The method allowed sensitive determination of $\mathrm{AFB}_{1}$ with $\mathrm{IC}_{50}$ of $22.3 \mathrm{pg} / \mathrm{mL}$, which enhanced 32 times compared to the traditional ELISA [76].

Although these approaches achieved superior sensitivity, most of them rely on traditional single-signal readout mode. And these strategies might encounter the limitation of inaccuracy for mycotoxins evaluation, which was partly ascribed to external interferences, such as nonstandard test processes, different operators, or diverse surrounding environments [77-79]. Recent development in mycotoxins immunoassays enable the integration of visual and various signal transduction techniques into dual-signal strategies, and thus offering multi models for mycotoxins detection because of their self-calibration. Typically, by using the changed multiple color and LSPR shifts of Au nanobipyramids etched by $\bullet \mathrm{OH}$ generated from HRP-catalyzed $\mathrm{H}_{2} \mathrm{O}_{2}$, and the changed photocurrent of $\mathrm{CdS}$ etched by the oxidized HRP. Wei et al. [80] developed an improved colorimetric and photoelectrometric immunoassay for ochratoxins (Figure 2C). The nanoliposomes as the vehicle for carrying more secondary antibodies and encapsulating HRP significantly amplified the detection signal, realizing the simultaneous detection of three ochratoxins (OTA, OTB, and OTC). The dual-modality immunoassay showed high sensitivity with LOD of 0.7 and $1.7 \mathrm{ng} / \mathrm{L}$ for photoelectrometric and colorimetric readouts, respectively. Attractively, the dual-modality response immunoassays showed a more accurate and reliable outcome compared with the single modality. 

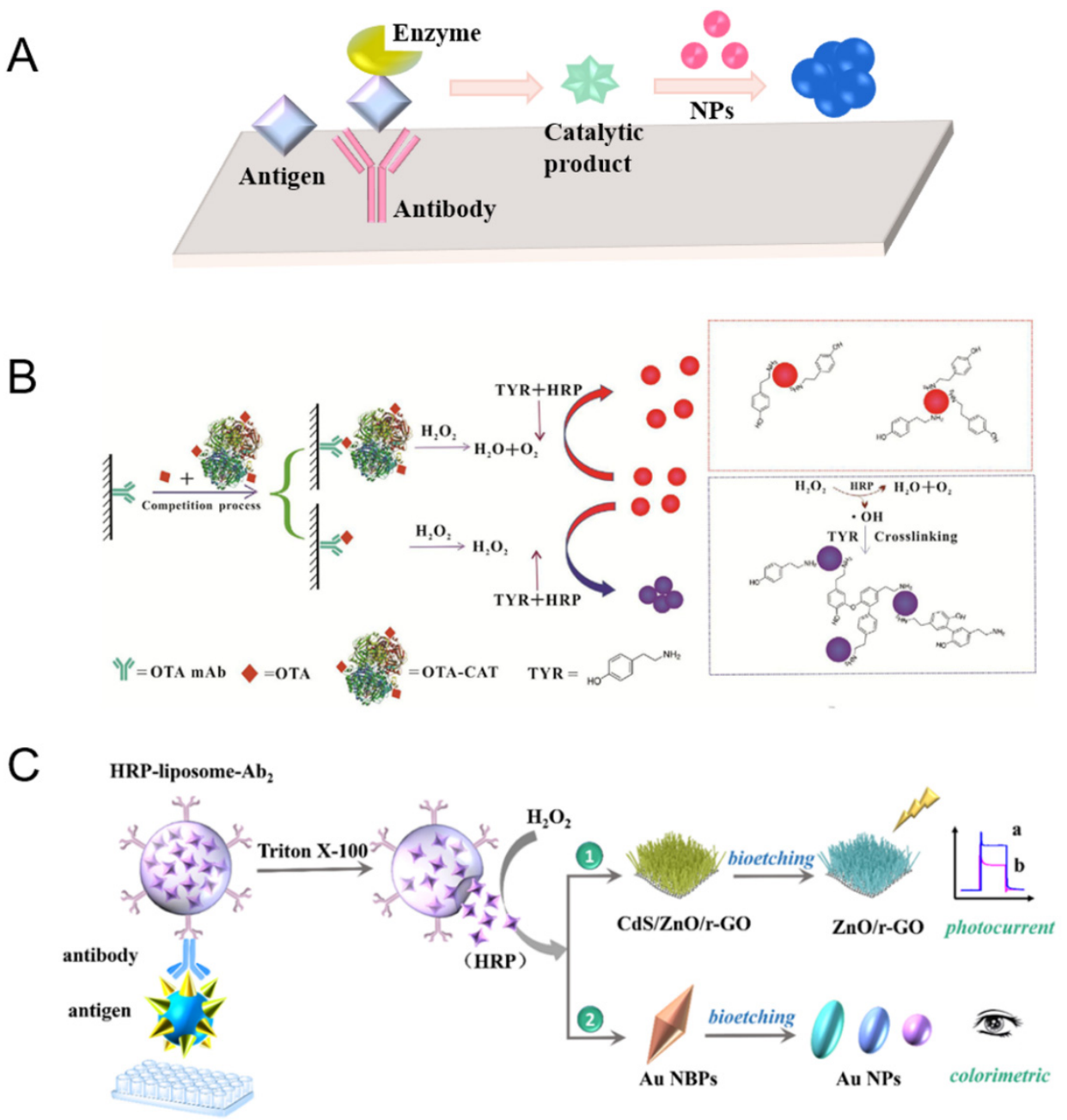

Figure 2. (A) The enzymes-catalyzed products-mediated nanomaterials for signal readout. (B) CATmediated AuNPs aggregation-based ELISA for OTA. Reprinted from ref [74]. Copyright 2018 Elsevier.(C) HRP-mediated Au nanobipyramids etching process-based immunoassay for ochratoxins. Reprinted from ref. [80]. Copyright 2019 American Chemical Society.

\subsection{Nanozyme for Signal Amplification}

Although natural enzymes are extensively used in various fields, their catalytic activities were still susceptible to the extreme environment, e.g., heat, $\mathrm{pH}$, organic solvents, mechanical stress, heavy metal, etc. Meanwhile, they present many shortcomings, such as high expense, low recyclability, poor operational stability and limited practical applications, e.g., the preparation, reaction, and storage requirements [81-83]. Nanomaterials-based artificial enzymes (nanozyme) have been particularly attractive since the discovery of $\mathrm{Fe}_{3} \mathrm{O}_{4}$ NPs with peroxidase-like activity by Yan's group in 2007 [84]. Nanozymes are ideal candidates for alternative natural enzymes due to their high catalytic activity, tunable catalytic activity and types, multienzyme mimetic activity, high stability, low cost, durability and ease of functionalization [62]. Nowadays, various nanozymes have been served as catalytic labels for multi-category signal amplification in newly developed immunoassays. Numerous studies revealed that metal NPs ( $\mathrm{Au}, \mathrm{Ag}, \mathrm{Pt}, \mathrm{Pd})[85,86]$, metal oxide NPs $\left(\mathrm{Fe}_{3} \mathrm{O}_{4}, \mathrm{CeO}_{2}, \mathrm{MnO}_{2}, \mathrm{CuO}\right.$ ) [87-92], carbon-based (graphene oxide, carbon nitride, carbon dots) [93-96], and MOFs-based nanomaterials [97-99] with peroxidase-, catalase-, oxidase-, superoxide dismutase-mimicking properties.

These nanozymes have been designed to amplify the sensing of mycotoxins (Figure 3A). For example, Xu et al. [100] developed an indirect competitive MOFs -linked immunosorbent assay for the high throughput and sensitive detection of $\mathrm{AFB}_{1}$ in grain drinks. 
Peroxidase-like activity of MOFs (MIL-88) was conjugated to a secondary antibody to substitute natural HRP-labeled secondary antibody. The MOFs-based immunoassay allowed to sensitively detect $\mathrm{AFB}_{1}$ with the LOD of $0.009 \mathrm{ng} / \mathrm{L}$ with 20 times improvement compared to the conventional ELISA. The enhanced sensitivity might arise from their good dispersity, more active sites, and pores of MOFs-labeled antibodies promoted the catalytic reaction between MOFs-labeled antibody nanozyme and substrate. Significantly, the immunoassay could successfully decrease the occurrence of false positives and false negatives during the detection of $\mathrm{AFB}_{1}$ (Figure $3 \mathrm{~B}$ ).

Furthermore, $\mathrm{Zhu}$ et al. [101] developed a competitive ELISA that was constructed to sensitively monitor OTA in millet samples through octahedral $\mathrm{Cu}_{2} \mathrm{O}$ nanoparticles etching of Au nanobipyramids. Peroxidase-mimicking activity of $\mathrm{Cu}_{2} \mathrm{O}$ could oxidize TMB in the presence of $\mathrm{H}_{2} \mathrm{O}_{2}$, and the yellow product $\mathrm{TMB}^{2+}$ could etch the Au nanobipyramids, triggering a significant longitudinal peak blue shift of local surface plasmon resonance. In this case, a dopamine-coated microplate was used to capture OTA antigens, and followed by the immunoreaction between OTA antibodies and the $\mathrm{Cu}_{2} \mathrm{O}$-labled secondary antibody. The growing concentration of OTA resulted in a decrease of $\mathrm{Cu}_{2} \mathrm{O}$-labled secondary antibody amount, further imposing adverse effects on the generation of catalytic product $\mathrm{TMB}^{2+}$ and the etching process of AuNRs (Figure 3C). The method allowed to sensitively detect OTA with LOD of $0.47 \mathrm{ng} / \mathrm{L}$.

Apart from the single nanozyme for signal amplification, multienzyme-based cascade catalysis is another important signal transduction and amplification strategy. In the catalytic cascade system, the decreased diffusion path of intermediates between the enzymes enables the improvement of unstable intermediates, facilitating their efficiency and specificity [102-104]. Meanwhile, the single substrate can be converted into more signal molecule through the multienzyme-associated continuous catalysis reaction and contributes to the signal amplification [68,83,105]. Lai et al. [105] proposed a competitive cascade amplified immunoassay for $\mathrm{AFB}_{1}$ detection in peanut samples by a combination of ascorbate oxidase $\left(\mathrm{AO}_{\mathrm{x}}\right) /$ anti- $\mathrm{AFB}_{1}$ antibody-labeled AuNPs and oxidase-mimics $\mathrm{MnO}_{2}$ (Figure 3D). With the assistance of ascorbic acid (AA), a blue $\mathrm{MnO}_{2}-\mathrm{TMB}$ system was converted into a colorless system because of the dissolution of $\mathrm{MnO}_{2}$ into $\mathrm{Mn}^{2+}$. Once introduced $\mathrm{AO}_{\mathrm{x}}$, the color change could be suppressed since $\mathrm{AO}_{\mathrm{x}}$ catalysis $\mathrm{AA}$ to dehydroascorbic acid. The cascade signal amplification remarkably improved the sensitivity of $\mathrm{AFB}_{1}$ with LOD of $6.5 \mathrm{pg} / \mathrm{mL}$, which approximately enhanced 15-, 7-, and 38-fold compared to the existing commercialized $\mathrm{AFB}_{1}$ kits (e.g., QuickingBiotech:100 ppt; Max Signals: $50 \mathrm{pg} / \mathrm{mL}$; MyBioSource: $250 \mathrm{pg} / \mathrm{mL}$ ). Similarly, Lai further developed a competitive immunoassay for sensitive screening $\mathrm{AFB}_{1}$ in a peanut sample (LOD: $0.1 \mathrm{ng} / \mathrm{mL}$ ), based on the just-in-time generation of an oxidase, mimics $\mathrm{MnO}_{2}$ through the reaction $\mathrm{KMnO}_{4}$ and $\mathrm{Mn}^{2+}$ with the assistance of $\mathrm{AO}_{\mathrm{x}}[106]$.

Similar to ELISA, LFI is another important visual immunoassay for nanomaterialslabeled one-step immunochromatographic paper-based point-of-care tests. LFI is widely used in food safety owing to its low cost, speed, and ease of use [107-109]. The components of LFI mainly include a sample pad, a nitrocellulose (NC) membrane containing the test and control zones, conjugate and absorbent pads from cellulose, and a polyvinyl chloride backing card for assembling the components [110]. Once the sample solution is dropped onto the sample pad, it can migrate along the strips driven by capillary forces. Then, the sample dissolves the detection reagent in the conjugation pad, followed by flows along the strip within the porous membrane, where the analyte and the signal reporter were captured on the test line, thereby leading to the generation of a detectable signal. The sensing principle of LFI for analytes mainly includes the competitive and sandwich types. Generally, the competitive LFI is utilized to analyze mycotoxins due to their low-molecular weight. For the competitive LFI, the analyte competes with the same molecule, or the analyte blocks the capture agent attached on reporter tags in conjugation [111,112]. The resultant detectable signal intensity of the test line decreased upon the growing concentration of mycotoxins. 
A

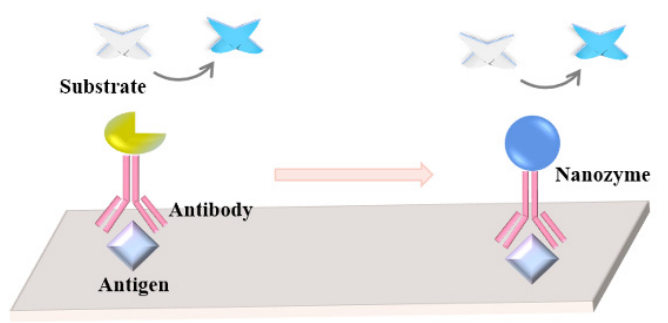

C

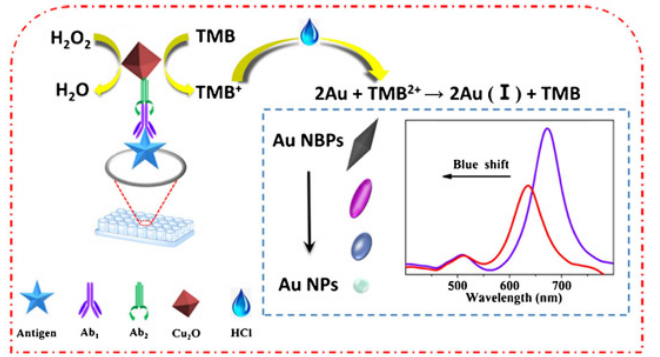

B

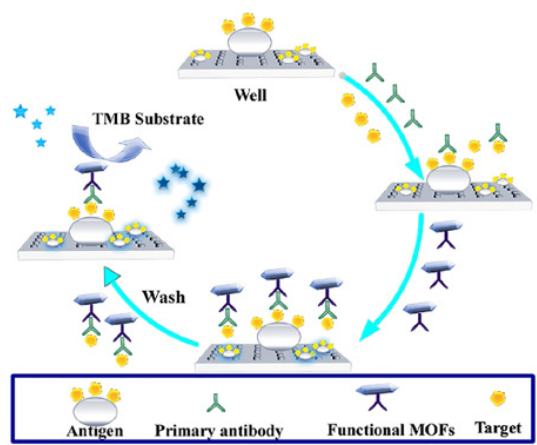

D

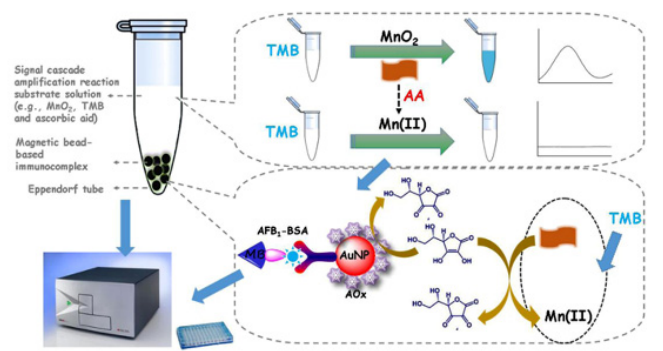

Figure 3. (A) Nanozyme-based immunoassays. (B) MOFs-linked immunosorbent assay for $\mathrm{AFB}_{1}$ detection. Reprinted from ref. [100]. Copyright 2021 Elsevier.(C) Peroxidase-like activity of $\mathrm{Cu}_{2} \mathrm{O}$ based immunoassay for OTA detection. Reprinted from ref. [101]. Copyright 2021 Springer Nature. (D) $\mathrm{MnO}_{2}-\mathrm{AO}_{\mathrm{x}}$ cascade amplified immunoassay for $\mathrm{AFB}_{1}$ detection. Reprinted from ref. [105]. Copyright 2017, Elsevier.

For colorimetric LFI, AuNPs are the common signal labeled material for visual output through non-covalent electrostatic adsorption of antibodies or antigens [113]. Aunanomaterials-based LFI have been extensively developed for analysis multiplex mycotoxins including $\mathrm{FB}_{1}$ [114], $\mathrm{AFB}_{1}$ [115], OTA [116], ZEN [117] etc. In addition, natural enzymes also provide signals through conjugating to mycotoxin-protein and are executed as the signal transducer to achieve visual detection, such as HRP-labeled antibodies or /antigen for immunological recognition construction LFI [118,119]. Nowadays, numerous nanozymes have been used to label antibodies or antigens for rapid visual LFI. The evidence of $\mathrm{Fe}_{3} \mathrm{O}_{4}$ nanozyme for enhanced detection Ebola virus with 100 times enhancement compared to the conventional AuNPs-based LFI, revealing the signal amplification ability of nanozyme [120]. Various fascinating nanozyme, such as AuPt nanoflowers [121], Pt nanocatalyst [122], Pt-Ni(OH) ${ }_{2}$ nanosheets [123], Prussian blue NPs (PBNPs) [124], have been used to construct LFI, and realized their widely application in food safety. For example, Tian et al. developed PBNPs as a marker signal LFI platform for OTA in soybeans samples. The new signal of PBNPs can be amplified via the TMB cascaded signal. The colorimetric signal of PBNPs accumulated on the test line through specific immune interactions, triggering the formation of a visible blue line. Meanwhile, the colorimetric signal could be further amplified via the peroxidase-mimic property of PBNPs. The resultant colorimetric images and grey intensity for OTA concentration were collected and analyzed by a smartphone and software Image J, respectively. This proposed LFI significantly improved the sensitivity of OTA with 2-3 orders of magnitude relative to commercial AuNPs-based LFI [125]. Although nanozyme have been extensively applied in food analysis, their poor substrate specificity, unclear mechanism, lack of standards and reference materials, and potential toxicity remained the major challenges for their further application.

\section{Conclusions and Outlook}

Mycotoxin contamination is a continuous global concern for food safety. Visual immunoassays remain simple, rapid, on-site detection of mycotoxins contamination as an alternative to traditional sophisticated techniques. The combination between conventional 
visual immunoassays and nanomaterials, novel visual immunoassays tend to be popular for mycotoxins by using the signal amplified strategies for tackling their inherent limited sensitivity. The representative immunoassays based on various nanomaterials could achieve the enhanced sensitive detection of mycotoxins using signal amplified strategies. Enzyme-immobilized onto nanomaterials, enzyme-mediated nanomaterials for amplified signal readout, nanozyme for amplifying the sensitivity of mycotoxins detection.

Although the aforementioned sensitive visual immunoassays for mycotoxins have revealed outstanding analytical performance and a fascinating prospect, many challenges still need to be tackled.

(1) The visual signal is obtained by the naked eye. Yet, the reliance on manual observation rather than instrumental measurement might cause large subjective uncertainty, as well as difficulty in quantitative data. The integration of digital technology [126] (e.g., machine vision) to simulate human visual ability and objective perception, the accurate and reliable results could be easily quantified, and thus reducing subjective errors in manual observations.

(2) Compared to the traditional immunoassays, the limited reproducibility and stability of nanomaterials-based immunoassays is the important obstacle for further application in food analysis due to their experimental and systemic factors. The standardization of nanomaterials preparation could effectively guarantee the reproducibility and stability of nanomaterials-based immunoassays.

(3) Most visual immunoassays are developed for single mycotoxin, while mycotoxins always co-occurred with the others in actual food samples. Thus, the simultaneous monitoring multi-mycotoxins by combing the multi-recognition elements in immunoassays facilitate to shorten the required time, save costs and alleviate the required labor.

(4) The integration of the visual analysis technology and multi-analysis technologies (e.g., magnetic, optical, and thermal properties, etc.), multi-signal immunoassays of mycotoxins contribute to minimum background signal and false-positive errors.

(5) Further exploiting the smart, automatic, miniaturized detector with the integration of smartphone, a portable and high-resolution device for the highly sensitive screening of mycotoxin contamination.

Author Contributions: M.L.: conceptualization, writing the original draft, and writing-review \& editing. Q.Z.: conceptualization, project administration, and funding acquisition. P.L.: funding acquisition, project administration, and supervision. All authors have read and agreed to the published version of the manuscript.

Funding: This work was supported by the National Key R\&D Program of China (2018YFC1602500), the Key Project of National Science Foundation of China (32030085), Agricultural Science and Technology Innovation Program of CAAS (CAAS-ZDRW202011), Natural Science Foundation of Hubei Province (2021CFB181).

Conflicts of Interest: The authors declare no conflict of interest.

\section{References}

1. Alshannaq, A.; Yu, J.-H. Occurrence, toxicity, and analysis of major mycotoxins in food. Int. J. Environ. Res. Public Health 2017, 14, 632. [CrossRef] [PubMed]

2. Sweeney, M.J.; Dobson, A.D.W. Mycotoxin production by Aspergillus, Fusarium and Penicillium species. Int. J. Food Microbiol. 1998, 43, 141-158. [CrossRef]

3. Chen, Y.; Chen, Q.; Han, M.; Zhou, J.; Gong, L.; Niu, Y.; Zhang, Y.; He, L.; Zhang, L. Development and optimization of a multiplex lateral flow immunoassay for the simultaneous determination of three mycotoxins in corn, rice and peanut. Food Chem. 2016, 213, 478-484. [CrossRef] [PubMed]

4. Luo, Y.; Liu, X.; Li, J. Updating techniques on controlling mycotoxins-A review. Food Control 2018, 89, 123-132. [CrossRef]

5. Yang, Y.; Li, G.; Wu, D.; Liu, J.; Li, X.; Luo, P.; Hu, N.; Wang, H.; Wu, Y. Recent advances on toxicity and determination methods of mycotoxins in foodstuffs. Trends Food Sci. Technol. 2020, 96, 233-252. [CrossRef]

6. Rossi, C.N.; Takabayashi, C.R.; Ono, M.A.; Saito, G.H.; Itano, E.N.; Kawamura, O.; Hirooka, E.Y.; Ono, E.Y.S. Immunoassay based on monoclonal antibody for aflatoxin detection in poultry feed. Food Chem. 2012, 132, 2211-2216. [CrossRef] 
7. Zhou, S.; Xu, L.; Kuang, H.; Xiao, J.; Xu, C. Immunoassays for rapid mycotoxin detection: State of the art. Analyst 2020, 145, 7088-7102. [CrossRef]

8. Singh, J.; Mehta, A. Rapid and sensitive detection of mycotoxins by advanced and emerging analytical methods: A review. Food Sci. Nutr. 2020, 8, 2183-2204. [CrossRef] [PubMed]

9. Yu, L.; Ma, F.; Zhang, L.; Li, P. Determination of aflatoxin B-1 and B-2 in vegetable oils using $\mathrm{Fe}_{3} \mathrm{O}_{4} / \mathrm{rGO}$ magnetic solid phase extraction coupled with high-performance liquid chromatography fluorescence with post-column photochemical derivatization. Toxins 2019, 11, 621. [CrossRef]

10. Andrade, P.D.; Dantas, R.R.; Moura-Alves, T.L.d.S.d.; Caldas, E.D. Determination of multi-mycotoxins in cereals and of total fumonisins in maize products using isotope labeled internal standard and liquid chromatography/tandem mass spectrometry with positive ionization. J. Chromatogr. A 2017, 1490, 138-147. [CrossRef]

11. Zhang, Y.; Pei, F.; Fang, Y.; Li, P.; Zhao, Y.; Shen, F.; Zou, Y.; Hu, Q. Comparison of concentration and health risks of 9 Fusarium mycotoxins in commercial whole wheat flour and refined wheat flour by multi-IAC-HPLC. Food Chem. 2019, 275, 763-769. [CrossRef] [PubMed]

12. Medina, D.A.V.; Borsatto, J.V.B.; Maciel, E.V.S.; Lancas, F.M. Current role of modern chromatography and mass spectrometry in the analysis of mycotoxins in food. TrAC Trends Anal. Chem. 2021, 135, 116156. [CrossRef]

13. Alsharif, A.M.A.; Choo, Y.-M.; Tan, G.-H. Detection of five mycotoxins in different food matrices in the Malaysian market by using validated liquid chromatography electrospray ionization triple quadrupole mass spectrometry. Toxins 2019, 11, 196. [CrossRef]

14. Yan, T.T.; Zhang, Z.W.; Zhang, Q.; Tang, X.Q.; Wang, D.; Hu, X.F.; Zhang, W.; Chen, X.M.; Li, P.W. Simultaneous determination for A. flavus-metabolizing mycotoxins by time-resolved fluorescent microbead or gold-enabling test strip in agricultural products based on monoclonal antibodies. Microchim. Acta 2020, 187, 653. [CrossRef] [PubMed]

15. Yang, H.L.; Zhang, Q.; Liu, X.L.; Yang, Y.Y.; Yang, Y.; Liu, M.Y.; Li, P.W.; Zhou, Y. Antibody-biotin-streptavidin-horseradish peroxidase (HRP) sensor for rapid and ultra-sensitive detection of fumonisins. Food Chem. 2020, 316, 126356. [CrossRef]

16. Beloglazova, N.V.; Graniczkowska, K.; Ediage, E.N.; Averkieva, O.; De Saeger, S. Sensitive flow-through immunoassay for rapid multiplex determination of cereal-borne mycotoxins in feed and feed ingredients. J. Agric. Food Chem. 2017, 65, 7131-7137. [CrossRef]

17. He, Q.-H.; Xu, Y.; Wang, D.; Kang, M.; Huang, Z.-B.; Li, Y.-P. Simultaneous multiresidue determination of mycotoxins in cereal samples by polyvinylidene fluoride membrane based dot immunoassay. Food Chem. 2012, 134, 507-512. [CrossRef]

18. Li, M.; Wang, H.M.; Sun, J.D.; Ji, J.; Ye, Y.L.; Lu, X.; Zhang, Y.Z.; Sun, X.L. Rapid, on-site, and sensitive detection of aflatoxin M1 in milk products by using time-resolved fluorescence microsphere test strip. Food Control 2021, 121, 107616. [CrossRef]

19. Xu, Y.; Ma, B.; Chen, E.J.; Yu, X.P.; Ye, Z.H.; Sun, C.X.; Zhang, M.Z. Dual fluorescent immunochromatographic assay for simultaneous quantitative detection of citrinin and zearalenone in corn samples. Food Chem. 2021, 336, 127713. [CrossRef]

20. Li, H.; Wang, D.; Tang, X.; Zhang, W.; Zhang, Q.; Li, P. Time-resolved fluorescence immunochromatography assay (TRFICA) for aflatoxin: Aiming at increasing strip method sensitivity. Front. Microbiol. 2020, 11, 676. [CrossRef]

21. Kaminiaris, M.D.; Mavrikou, S.; Georgiadou, M.; Paivana, G.; Tsitsigiannis, D.I.; Kintzios, S. An impedance based electrochemical immunosensor for aflatoxin B-1 monitoring in pistachio matrices. Chemosensors 2020, 8, 121. [CrossRef]

22. Kudr, J.; Zhao, L.; Nguyen, E.P.; Arola, H.; Nevanen, T.K.; Adam, V.; Zitka, O.; Merkoci, A. Inkjet-printed electrochemically reduced graphene oxide microelectrode as a platform for HT-2 mycotoxin immunoenzymatic biosensing. Biosens. Bioelectron. 2020, 156, 112109. [CrossRef] [PubMed]

23. Kunene, K.; Weber, M.; Sabela, M.; Voiry, D.; Kanchi, S.; Bisetty, K.; Bechelany, M. Highly-efficient electrochemical label-free immunosensor for the detection of ochratoxin A in coffee samples. Sens. Actuators B Chem. 2020, 305, 127438. [CrossRef]

24. Hou, S.; Ma, Z.; Meng, H.; Xu, Y.; He, Q. Ultrasensitive and green electrochemical immunosensor for mycotoxin ochratoxin A based on phage displayed mimotope peptide. Talanta 2019, 194, 919-924. [CrossRef]

25. Quan, Y.; Zhang, Y.; Wang, S.; Lee, N.; Kennedy, I.R. A rapid and sensitive chemiluminescence enzyme-linked immunosorbent assay for the determination of fumonisin B1 in food samples. Anal. Chim. Acta 2006, 580, 1-8. [CrossRef] [PubMed]

26. Ren, X.; Lu, P.; Feng, R.; Zhang, T.; Zhang, Y.; Wu, D.; Wei, Q. An ITO-based point-of-care colorimetric immunosensor for ochratoxin A detection. Talanta 2018, 188, 593-599. [CrossRef]

27. Bazin, I.; Nabais, E.; Lopez-Ferber, M. Rapid visual tests: Fast and reliable detection of ochratoxin A. Toxins 2010, 2, $2230-2241$. [CrossRef]

28. Garden, S.R.; Strachan, N.J.C. Novel colorimetric immunoassay for the detection of aflatoxin B1. Anal. Chim. Acta 2001, 444, 187-191. [CrossRef]

29. Yu, Z.; Cai, G.; Liu, X.; Tang, D. Pressure-based biosensor integrated with a flexible pressure sensor and an electrochromic device for visual detection. Anal. Chem. 2021, 93, 2916-2925. [CrossRef]

30. Wang, L.; He, K.; Wang, X.; Wang, Q.; Quan, H.; Wang, P.; Xu, X. Recent progress in visual methods for aflatoxin detection. Crit. Rev. Food Sci. Nutr. 2021. [CrossRef]

31. Majdinasab, M.; Ben Aissa, S.; Marty, J.L. Advances in colorimetric strategies for mycotoxins detection: Toward rapid industrial monitoring. Toxins 2021, 13, 13. [CrossRef] [PubMed]

32. Liu, B.-H.; Chu, K.C.; Yu, F.-Y. Novel monoclonal antibody-based sensitive enzyme-linked immunosorbent assay and rapid immunochromatographic strip for detecting aflatoxin M1 in milk. Food Control 2016, 66, 1-7. [CrossRef] 
33. Wang, Y.; Li, P.; Zhang, Q.; Hu, X.; Zhang, W. A toxin-free enzyme-linked immunosorbent assay for the analysis of aflatoxins based on a VHH surrogate standard. Anal. Bioanal. Chem. 2016, 408, 6019-6026. [CrossRef] [PubMed]

34. Li, Y.; Jin, G.; Liu, L.; Xiao, J.; Kuang, H. Fast determination of citreoviridin residues in rice using a monoclonal antibody-based immunochromatographic strip assay. Food Agric. Immunol. 2020, 31, 893-906. [CrossRef]

35. Badea, M.; Micheli, L.; Messia, M.C.; Candigliota, T.; Marconi, E.; Mottram, T.; Velasco-Garcia, M.; Moscone, D.; Palleschi, G. Aflatoxin M1 determination in raw milk using a flow-injection immunoassay system. Anal. Chim. Acta 2004, 520, 141-148. [CrossRef]

36. Qu, J.W.; Xie, H.J.; Zhang, S.Y.; Luo, P.J.; Guo, P.; Chen, X.X.; Ke, Y.B.; Zhuang, J.Y.; Zhou, F.M.; Jiang, W.X. Multiplex flow cytometric immunoassays for high-throughput screening of multiple mycotoxin residues in milk. Food Anal. Methods 2019, 12, 877-886. [CrossRef]

37. Li, Y.; Zhang, N.; Wang, H.; Zhao, Q. An immunoassay for ochratoxin a using tetramethylrhodamine-labeled ochratoxin a as a probe based on a binding-induced change in fluorescence intensity. Analyst 2020, 145, 651-655. [CrossRef]

38. Tian, Y.; Bu, T.; Zhang, M.; Sun, X.; Jia, P.; Wang, Q.; Liu, Y.; Bai, F.; Zhao, S.; Wang, L. Metal-polydopamine framework based lateral flow assay for high sensitive detection of tetracycline in food samples. Food Chem. 2021, 339, 127854. [CrossRef]

39. Tan, X.; Wang, X.; Zhang, L.; Liu, L.; Zheng, G.; Li, H.; Zhou, F. Stable and photothermally efficient antibody-covered $\mathrm{Cu}_{3}\left(\mathrm{PO}_{4}\right)_{2} @$ polydopamine nanocomposites for sensitive and cost-effective immunoassays. Anal. Chem. 2019, 91, 8274-8279. [CrossRef]

40. Cheng, N.; Song, Y.; Zeinhom, M.M.A.; Chang, Y.-C.; Sheng, L.; Li, H.; Du, D.; Li, L.; Zhu, M.-J.; Luo, Y.; et al. Nanozyme-mediated dual immunoassay integrated with smartphone for use in simultaneous detection of pathogens. ACS Appl. Mater. Interfaces 2017, 9, 40671-40680. [CrossRef]

41. Yao, X.; Wang, Z.; Zhao, M.; Liu, S.; Su, L.; Dou, L.; Li, T.; Wang, J.; Zhang, D. Graphite-like carbon nitride-laden gold nanoparticles as signal amplification label for highly sensitive lateral flow immunoassay of $17 \beta$-estradiol. Food Chem. 2021, 347, 129001. [CrossRef]

42. Oh, S.; Kim, J.; Tran, V.T.; Lee, D.K.; Ahmed, S.R.; Hong, J.C.; Lee, J.; Park, E.Y.; Lee, J. Magnetic nanozyme-linked immunosorbent assay for ultrasensitive influenza a virus detection. ACS Appl. Mater. Interfaces 2018, 10, 12534-12543. [CrossRef]

43. Zhang, X.; Song, M.; Yu, X.; Wang, Z.; Ke, Y.; Jiang, H.; Li, J.; Shen, J.; Wen, K. Development of a new broad-specific monoclonal antibody with uniform affinity for aflatoxins and magnetic beads-based enzymatic immunoassay. Food Control 2017, 79, 309-316. [CrossRef]

44. Lai, W.; Wei, Q.; Zhuang, J.; Lu, M.; Tang, D. Fenton reaction-based colorimetric immunoassay for sensitive detection of brevetoxin B. Biosens. Bioelectron. 2016, 80, 249-256. [CrossRef]

45. Yan, C.; Wang, Q.; Yang, Q.; Wu, W. Recent advances in aflatoxins detection based on nanomaterials. Nanomaterials 2020, 10, 1626. [CrossRef] [PubMed]

46. Ambrosi, A.; Airo, F.; Merkoci, A. Enhanced gold nanoparticle based ELISA for a breast cancer biomarker. Anal. Chem. 2010, 82, 1151-1156. [CrossRef]

47. Zhou, Y.; Tian, X.L.; Li, Y.S.; Pan, F.G.; Zhang, Y.Y.; Zhang, J.H.; Yang, L.; Wang, X.R.; Ren, H.L.; Lu, S.Y.; et al. An enhanced ELISA based on modified colloidal gold nanoparticles for the detection of $\mathrm{Pb}(\mathrm{II})$. Biosens. Bioelectron. 2011, 26, 3700-3704. [CrossRef] [PubMed]

48. Zha, Y.H.; Zhou, Y. Functional nanomaterials based immunological detection of aflatoxin B-1: A review. World Mycotoxin J. 2020, 13, 151-162. [CrossRef]

49. Liang, M.; Yan, X. Nanozymes: From new concepts, mechanisms, and standards to applications. Acc. Chem. Res. 2019, 52, 2190-2200. [CrossRef]

50. Huang, Y.; Ren, J.; Qu, X. Nanozymes: Classification, catalytic mechanisms, activity regulation, and applications. Chem. Rev. 2019, 119, 4357-4412. [CrossRef]

51. Wu, L.; Li, G.; Xu, X.; Zhu, L.; Huang, R.; Chen, X. Application of nano-ELISA in food analysis: Recent advances and challenges. TrAC Trends Anal. Chem. 2019, 113, 140-156. [CrossRef]

52. Gao, Y.; Zhou, Y.; Chandrawati, R. Metal and metal oxide nanoparticles to enhance the performance of enzyme-linked immunosorbent assay (ELISA). ACS Appl. Nano Mater. 2020, 3, 1-21. [CrossRef]

53. Heussner, A.H.; Ausländer, S.; Dietrich, D.R. Development and characterization of a monoclonal antibody against ochratoxin b and its application in ELISA. Toxins 2010, 2, 1582-1594. [CrossRef]

54. Huang, X.; Liu, Y.; Yung, B.; Xiong, Y.; Chen, X. Nanotechnology-enhanced no-wash biosensors for in vitro diagnostics of cancer. ACS Nano 2017, 11, 5238-5292. [CrossRef] [PubMed]

55. Li, P.; Zhang, Q.; Zhang, W.; Zhang, J.; Chen, X.; Jiang, J.; Xie, L.; Zhang, D. Development of a class-specific monoclonal antibody-based ELISA for aflatoxins in peanut. Food Chem. 2009, 115, 313-317. [CrossRef]

56. He, T.; Wang, Y.; Li, P.; Zhang, Q.; Lei, J.; Zhang, Z.; Ding, X.; Zhou, H.; Zhang, W. Nanobody-based enzyme immunoassay for aflatoxin in agro-products with high tolerance to cosolvent methanol. Anal. Chem. 2014, 86, 8873-8880. [CrossRef]

57. Wu, Y.; Yu, J.; Li, F.; Li, J.; Shen, Z. A Calibration curve implanted enzyme-linked immunosorbent assay for simultaneously quantitative determination of multiplex mycotoxins in cereal samples, Soybean and Peanut. Toxins 2020, 12, 718. [CrossRef] [PubMed] 
58. Guan, D.; Li, P.; Zhang, Q.; Zhang, W.; Zhang, D.; Jiang, J. An ultra-sensitive monoclonal antibody-based competitive enzyme immunoassay for aflatoxin M-1 in milk and infant milk products. Food Chem. 2011, 125, 1359-1364. [CrossRef]

59. Jiang, W.; Wang, Z.; Noelke, G.; Zhang, J.; Niu, L.; Shen, J. Simultaneous determination of aflatoxin b-1 and aflatoxin m-1 in food matrices by enzyme-linked immunosorbent assay. Food Anal. Methods 2013, 6, 767-774. [CrossRef]

60. Guesdon, J.-L. Immunoenzymatic techniques applied to the specific detection of nucleic acids: A review. J. Immunol. Methods 1992, 150, 33-49. [CrossRef]

61. Sun, Z.; Wang, X.; Chen, Q.; Yun, Y.; Tang, Z.; Liu, X. Nanobody-alkaline phosphatase fusion protein-based enzyme-linked immunosorbent assay for one-step detection of ochratoxin A in rice. Sensors 2018, 18, 4044. [CrossRef]

62. Tang, Z.; Wang, X.; Lv, J.; Hu, X.; Liu, X. One-step detection of ochratoxin A in cereal by dot immunoassay using a nanobodyalkaline phosphatase fusion protein. Food Control 2018, 92, 430-436. [CrossRef]

63. Shu, M.; Xu, Y.; Liu, X.; Li, Y.; He, Q.; Tu, Z.; Fu, J.; Gee, S.J.; Hammock, B.D. Anti-idiotypic nanobody-alkaline phosphatase fusion proteins: Development of a one-step competitive enzyme immunoassay for fumonisin B1 detection in cereal. Anal. Chim. Acta 2016, 924, 53-59. [CrossRef]

64. Yan, J.; Wang, J.; Zhao, M.P.; Chang, W.B. Determination of papaverine by biotin-avidin amplified ELISA. Anal. Lett. 2004, 37, 2977-2989. [CrossRef]

65. Zhang, X.; Wu, D.; Zhou, X.; Yu, Y.; Liu, J.; Hu, N.; Wang, H.; Li, G.; Wu, Y. Recent progress in the construction of nanozyme-based biosensors and their applications to food safety assay. TrAC Trends Anal. Chem. 2019, 121, 115668. [CrossRef]

66. Wang, Q.Q.; Wei, H.; Zhang, Z.Q.; Wang, E.K.; Dong, S.J. Nanozyme: An emerging alternative to natural enzyme for biosensing and immunoassay. TrAC Trends Anal. Chem. 2018, 105, 218-224. [CrossRef]

67. Niu, X.; Cheng, N.; Ruan, X.; Du, D.; Lin, Y. Review-nanozyme-based immunosensors and immunoassays: Recent developments and future trends. J. Electrochem. Soc. 2020, 167, 037508. [CrossRef]

68. Xiong, Y.; Leng, Y.; Li, X.; Huang, X.; Xiong, Y. Emerging strategies to enhance the sensitivity of competitive ELISA for detection of chemical contaminants in food samples. TrAC Trends Anal. Chem. 2020, 126, 115861. [CrossRef]

69. Lei, C.; Xu, C.; Nouwens, A.; Yu, C. Ultrasensitive ELISA(+) enhanced by dendritic mesoporous silica nanoparticles. J. Mater. Chem. B 2016, 4, 4975-4979. [CrossRef] [PubMed]

70. Zhu, Y.; Liu, C.-L.; Xie, Z.-J.; Liu, L.-Q.; Peng, C.-F.; Xue, F. Botryoid-shaped nanoparticles-enhanced ELISA for ochratoxin A. Food Agric. Immunol. 2017, 28, 299-309. [CrossRef]

71. Li, Z.; Sheng, W.; Liu, Q.; Li, S.; Shi, Y.; Zhang, Y.; Wang, S. Development of a gold nanoparticle enhanced enzyme linked immunosorbent assay based on monoclonal antibodies for the detection of fumonisin B-1, B-2, and B-3 in maize. Anal. Methods 2018, 10, 3506-3513. [CrossRef]

72. Liu, Z.; Wang, X.; Dong, F.; Li, Y.; Guo, Y.; Liu, X.; Xu, J.; Wu, X.; Zheng, Y. Ultrasensitive immunoassay for detection of zearalenone in agro-products using enzyme and antibody co-embedded zeolitic imidazolate framework as labels. J. Hazard. Mater. 2021, 412, 125276. [CrossRef] [PubMed]

73. Huang, X.; Chen, R.; Xu, H.; Lai, W.; Xiong, Y. Nanospherical brush as catalase container for enhancing the detection sensitivity of competitive plasmonic ELISA. Anal. Chem. 2016, 88, 1951-1958. [CrossRef]

74. Liang, Y.; Huang, X.; Chen, X.; Zhang, W.; Ping, G.; Xiong, Y. Plasmonic ELISA for naked-eye detection of ochratoxin A based on the tyramine- $\mathrm{H}_{2} \mathrm{O}_{2}$ amplification system. Sens. Actuators B Chem. 2018, 259, 162-169. [CrossRef]

75. Zhan, S.; Zheng, L.; Zhou, Y.; Wu, K.; Duan, H.; Huang, X.; Xiong, Y. A gold growth-based plasmonic ELISA for the sensitive detection of Fumonisin B1 in maize. Toxins 2019, 11, 323. [CrossRef] [PubMed]

76. Xiong, Y.; Pei, K.; Wu, Y.; Duan, H.; Lai, W.; Xiong, Y. Plasmonic ELISA based on enzyme-assisted etching of Au nanorods for the highly sensitive detection of aflatoxin B-1 in corn samples. Sens. Actuators B Chem. 2018, 267, 320-327. [CrossRef]

77. Wang, M.; Zhou, X.; Wang, S.; Xie, X.; Wang, Y.; Su, X. Fabrication of bioresource-derived porous carbon-supported iron as an efficient oxidase mimic for dual-channel biosensing. Anal. Chem. 2021, 93, 3130-3137. [CrossRef] [PubMed]

78. Huang, Y.; Ge, J.; Chen, H.; Wang, Z.; Han, J.; Xie, G.; Chen, S. Dual-signal readout aptasensor for electrochemical and colorimetric assay using a bifunctional Ni-Fe PBA probe. Sens. Actuators B Chem. 2021, 327, 128871. [CrossRef]

79. Chang, J.; Lv, W.; Li, Q.; Li, H.; Li, F. One-step synthesis of methylene blue-encapsulated zeolitic imidazolate framework for dual-signal fluorescent and homogeneous electrochemical biosensing. Anal. Chem. 2020, 92, 8959-8964. [CrossRef]

80. Wei, J.; Chen, H.; Chen, H.; Cui, Y.; Qileng, A.; Qin, W.; Liu, W.; Liu, Y. Multifunctional peroxidase-encapsulated nanoliposomes: Bioetching-induced photoelectrometric and colorimetric immunoassay for broad-spectrum detection of Ochratoxins. ACS Appl. Mater. Interfaces 2019, 11, 23832-23839. [CrossRef]

81. Payal, A.; Krishnamoorthy, S.; Elumalai, A.; Moses, J.A.; Anandharamakrishnan, C. A Review on recent developments and applications of nanozymes in food safety and quality analysis. Food Anal. Methods 2021, 14, 1537-1558. [CrossRef]

82. Jia, M.; Liao, X.; Fang, L.; Jia, B.; Liu, M.; Li, D.; Zhou, L.; Kong, W. Recent advances on immunosensors for mycotoxins in foods and other commodities. TrAC Trends Anal. Chem. 2021, 136, 116193. [CrossRef]

83. Xu, W.Q.; Jiao, L.; Wu, Y.; Hu, L.Y.; Gu, W.L.; Zhu, C.Z. Metal-organic frameworks enhance biomimetic cascade catalysis for biosensing. Adv. Mater. 2021, 33, 2005172. [CrossRef]

84. Gao, L.Z.; Zhuang, J.; Nie, L.; Zhang, J.B.; Zhang, Y.; Gu, N.; Wang, T.H.; Feng, J.; Yang, D.L.; Perrett, S.; et al. Intrinsic peroxidase-like activity of ferromagnetic nanoparticles. Nat. Nanotechnol. 2007, 2, 577-583. [CrossRef] 
85. Zhi, L.-J.; Sun, A.-L. Platinum nanozyme-encapsulated poly(amidoamine) dendrimer for voltammetric immunoassay of progastrin-releasing peptide. Anal. Chim. Acta 2020, 1134, 106-114. [CrossRef] [PubMed]

86. Yao, S.; Li, J.; Pang, B.; Wang, X.; Shi, Y.; Song, X.; Xu, K.; Wang, J.; Zhao, C. Colorimetric immunoassay for rapid detection of Staphylococcus aureus based on etching-enhanced peroxidase-like catalytic activity of gold nanoparticles. Microchim. Acta 2020, 187, 504. [CrossRef] [PubMed]

87. Li, J.; Cao, Y.; Hinman, S.S.; McKeating, K.S.; Guan, Y.; Hu, X.; Cheng, Q.; Yang, Z. Efficient label-free chemiluminescent immunosensor based on dual functional cupric oxide nanorods as peroxidase mimics. Biosens. Bioelectron. 2018, 100, 304-311. [CrossRef] [PubMed]

88. Lian, J.; Liu, P.; Jin, C.; Shi, Z.; Luo, X.; Liu, Q. Perylene diimide-functionalized $\mathrm{CeO}_{2}$ nanocomposite as a peroxidase mimic for colorimetric determination of hydrogen peroxide and glutathione. Microchim. Acta 2019, 186, 332. [CrossRef]

89. Wu, J.; Yang, Q.; Li, Q.; Li, H.; Li, F. Two-dimensional $\mathrm{MnO}_{2}$ nanozyme-mediated homogeneous electrochemical detection of organophosphate pesticides without the interference of $\mathrm{H}_{2} \mathrm{O}_{2}$ and color. Anal. Chem. 2021, 93, 4084-4091. [CrossRef]

90. Ge, J.; Yu, J.-H.; Yang, H.; Yang, D.; Cai, R. Human serum albumin templated $\mathrm{MnO}_{2}$ nanosheets as an efficient biomimetic oxidase for biomolecule sensing. J. Mater. Chem. B 2020, 8, 11090-11095. [CrossRef] [PubMed]

91. Huang, X.; Xia, F.; Nan, Z. Fabrication of $\mathrm{FeS}_{2} / \mathrm{SiO}_{2}$ double mesoporous hollow spheres as an artificial peroxidase and rapid determination of $\mathrm{H}_{2} \mathrm{O}_{2}$ and glutathione. ACS Appl. Mater. Interfaces 2020, 12, 46539-46548. [CrossRef]

92. Chen, W.; Chen, J.; Liu, A.-L.; Wang, L.-M.; Li, G.-W.; Lin, X.-H. Peroxidase-like activity of cupric oxide nanoparticle. ChemCatChem 2011, 3, 1151-1154. [CrossRef]

93. Song, Y.; Qu, K.; Zhao, C.; Ren, J.; Qu, X. Graphene oxide: Intrinsic peroxidase catalytic activity and its application to glucose detection. Adv. Mater. 2010, 22, 2206-2210. [CrossRef]

94. Tian, J.; Liu, Q.; Asiri, A.M.; Qusti, A.H.; Al-Youbi, A.O.; Sun, X. Ultrathin graphitic carbon nitride nanosheets: A novel peroxidase mimetic, Fe doping-mediated catalytic performance enhancement and application to rapid, highly sensitive optical detection of glucose. Nanoscale 2013, 5, 11604-11609. [CrossRef] [PubMed]

95. Zhang, J.; Lu, X.; Tang, D.; Wu, S.; Hou, X.; Liu, J.; Wu, P. Phosphorescent carbon dots for highly efficient oxygen photosensitization and as photo-oxidative nanozymes. ACS Appl. Mater. Interfaces 2018, 10, 40808-40814. [CrossRef] [PubMed]

96. Shi, W.; Wang, Q.; Long, Y.; Cheng, Z.; Chen, S.; Zheng, H.; Huang, Y. Carbon nanodots as peroxidase mimetics and their applications to glucose detection. Chem. Commun. 2011, 47, 6695-6697. [CrossRef]

97. Xia, H.; Li, N.; Huang, W.; Song, Y.; Jiang, Y. Enzymatic cascade reactions mediated by highly efficient biomimetic quasi metal-organic frameworks. ACS Appl. Mater. Interfaces 2021, 13, 22240-22253. [CrossRef]

98. Yuan, A.; Lu, Y.; Zhang, X.; Chen, Q.; Huang, Y. Two-dimensional iron MOF nanosheet as a highly efficient nanozyme for glucose biosensing. J. Mater. Chem. B 2020, 8, 9295-9303. [CrossRef]

99. Guo, J.; Wu, S.; Wang, Y.; Zhao, M. A label-free fluorescence biosensor based on a bifunctional MIL-101(Fe) nanozyme for sensitive detection of choline and acetylcholine at nanomolar level. Sens. Actuators B Chem. 2020, 312, 128021. [CrossRef]

100. Xu, Z.; Long, L.-1.; Chen, Y.-q.; Chen, M.-L.; Cheng, Y.-H. A nanozyme-linked immunosorbent assay based on metal-organic frameworks (MOFs) for sensitive detection of aflatoxin B-1. Food Chem. 2021, 338, 128039. [CrossRef] [PubMed]

101. Zhu, H.; Liu, C.; Liu, X.; Quan, Z.; Liu, W.; Liu, Y. A multi-colorimetric immunosensor for visual detection of ochratoxin A by mimetic enzyme etching of gold nanobipyramids. Microchim. Acta 2021, 188, 62. [CrossRef] [PubMed]

102. Vázquez-González, M.; Wang, C.; Willner, I. Biocatalytic cascades operating on macromolecular scaffolds and in confined environments. Nat. Catal. 2020, 3, 256-273. [CrossRef]

103. Kuzmak, A.; Carmali, S.; von Lieres, E.; Russell, A.J.; Kondrat, S. Can enzyme proximity accelerate cascade reactions? Sci. Rep. 2019, 9, 455. [CrossRef]

104. Gao, Z.; Hou, L.; Xu, M.; Tang, D. Enhanced colorimetric immunoassay accompanying with enzyme cascade amplification strategy for ultrasensitive detection of low-abundance protein. Sci. Rep. 2014, 4, 3966. [CrossRef]

105. Lai, W.; Wei, Q.; Xu, M.; Zhuang, J.; Tang, D. Enzyme-controlled dissolution of $\mathrm{MnO}_{2}$ nanoflakes with enzyme cascade amplification for colorimetric immunoassay. Biosens. Bioelectron. 2017, 89, 645-651. [CrossRef] [PubMed]

106. Lai, W.; Zeng, Q.; Tang, J.; Zhang, M.; Tang, D. A conventional chemical reaction for use in an unconventional assay: A colorimetric immunoassay for aflatoxin B-1 by using enzyme-responsive just-in-time generation of a $\mathrm{MnO}_{2}$ based nanocatalyst. Microchim. Acta 2018, 185, 92. [CrossRef] [PubMed]

107. Liu, Y.; Zhan, L.; Qin, Z.; Sackrison, J.; Bischof, J.C. Ultrasensitive and highly specific lateral flow assays for point-of-care diagnosis. ACS Nano 2021, 15, 3593-3611. [CrossRef]

108. Bishop, J.D.; Hsieh, H.V.; Gasperino, D.J.; Weigl, B.H. Sensitivity enhancement in lateral flow assays: A systems perspective. Lab Chip 2019, 19, 2486. [CrossRef]

109. Yu, S.; He, L.; Yu, F.; Liu, L.; Qu, C.; Qu, L.; Liu, J.; Wu, Y.; Wu, Y. A lateral flow assay for simultaneous detection of Deoxynivalenol, Fumonisin B-1 and Aflatoxin B-1. Toxicon 2018, 156, 23-27. [CrossRef]

110. Bahadır, E.B.; Sezgintürk, M.K. Lateral flow assays: Principles, designs and labels. TrAC Trends Anal. Chem. 2016, 82, 286-306. [CrossRef]

111. Mahmoudi, T.; de la Guardia, M.; Shirdel, B.; Mokhtarzadeh, A.; Baradaran, B. Recent advancements in structural improvements of lateral flow assays towards point-of-care testing. TrAC Trends Anal. Chem. 2019, 116, 13-30. [CrossRef] 
112. Xing, K.-Y.; Shan, S.; Liu, D.-F.; Lai, W.-H. Recent advances of lateral flow immunoassay for mycotoxins detection. TrAC Trends Anal. Chem. 2020, 133, 116087. [CrossRef]

113. Wu, L.; Wang, M.; Wei, D. Advances in gold nanoparticles for mycotoxin analysis. Analyst 2021, 146, 1793-1806. [CrossRef]

114. Ren, W.; Huang, Z.; Xu, Y.; Li, Y.; Ji, Y.; Su, B. Urchin-like gold nanoparticle-based immunochromatographic strip test for rapid detection of fumonisin B-1 in grains. Anal. Bioanal. Chem. 2015, 407, 7341-7348. [CrossRef]

115. Ji, Y.; Ren, M.; Li, Y.; Huang, Z.; Shu, M.; Yang, H.; Xiong, Y.; Xu, Y. Detection of aflatoxin B-1 with immunochromatographic test strips: Enhanced signal sensitivity using gold nanoflowers. Talanta 2015, 142, 206-212. [CrossRef] [PubMed]

116. Anfossi, L.; Di Nardo, F.; Giovannoli, C.; Passini, C.; Baggiani, C. Increased sensitivity of lateral flow immunoassay for ochratoxin A through silver enhancement. Anal. Bioanal. Chem. 2013, 405, 9859-9867. [CrossRef]

117. Xu, S.; Zhang, G.; Fang, B.; Xiong, Q.; Duan, H.; Lai, W. Lateral flow immunoassay based on polydopamine-coated gold nanoparticles for the sensitive detection of zearalenone in maize. ACS Appl. Mater. Interfaces 2019, 11, 31283-31290. [CrossRef]

118. Mirasoli, M.; Buragina, A.; Dolci, L.S.; Simoni, P.; Anfossi, L.; Giraudi, G.; Roda, A. Chemiluminescence-based biosensor for fumonisins quantitative detection in maize samples. Biosens. Bioelectron. 2012, 32, 283-287. [CrossRef] [PubMed]

119. dos Santos, G.P.; Correa, C.C.; Kubota, L.T. A simple, sensitive and reduced cost paper-based device with low quantity of chemicals for the early diagnosis of Plasmodium falciparum malaria using an enzyme-based colorimetric assay. Sens. Actuators $B$ Chem. 2018, 255, 2113-2120. [CrossRef]

120. Duan, D.; Fan, K.; Zhang, D.; Tan, S.; Liang, M.; Liu, Y.; Zhang, J.; Zhang, P.; Liu, W.; Qiu, X.; et al. Nanozyme-strip for rapid local diagnosis of Ebola. Biosens. Bioelectron. 2015, 74, 134-141. [CrossRef] [PubMed]

121. Zhang, J.; Yu, Q.C.; Qiu, W.W.; Li, K.; Qian, L.S.; Zhang, X.J.; Liu, G.D. Gold-platinum nanoflowers as a label and as an enzyme mimic for use in highly sensitive lateral flow immunoassays: Application to detection of rabbit IgG. Microchim. Acta 2019, $186,357$. [CrossRef]

122. Loynachan, C.N.; Thomas, M.R.; Gray, E.R.; Richards, D.A.; Kim, J.; Miller, B.S.; Brookes, J.C.; Agarwal, S.; Chudasama, V.; McKendry, R.A.; et al. Platinum nanocatalyst amplification: Redefining the gold standard for lateral flow immunoassays with ultrabroad dynamic range. ACS Nano 2018, 12, 279-288. [CrossRef]

123. Cheng, N.; Shi, Q.; Zhu, C.; Li, S.; Lin, Y.; Du, D. Pt-Ni(OH $)_{2}$ nanosheets amplified two-way lateral flow immunoassays with smartphone readout for quantification of pesticides. Biosens. Bioelectron. 2019, 142, 111498. [CrossRef]

124. Liu, S.; Dou, L.; Yao, X.; Zhang, W.; Zhao, M.; Yin, X.; Sun, J.; Zhang, D.; Wang, J. Nanozyme amplification mediated on-demand multiplex lateral flow immunoassay with dual-readout and broadened detection range. Biosens. Bioelectron. 2020, $169,112610$. [CrossRef] [PubMed]

125. Tian, M.; Xie, W.; Zhang, T.; Liu, Y.; Lu, Z.; Li, C.M.; Liu, Y. A sensitive lateral flow immunochromatographic strip with prussian blue nanoparticles mediated signal generation and cascade amplification. Sens. Actuators B Chem. 2020, 309, 127728. [CrossRef]

126. Liu, H.; Li, Z.; Shen, R.; Li, Z.; Yang, Y.; Yuan, Q. Point-of-care pathogen testing using photonic crystals and machine vision for diagnosis of urinary tract infections. Nano Lett. 2021, 21, 2854-2860. [CrossRef] [PubMed] 